\title{
THE ROLE OF GOVERNMENT IN REVITALIZATION OF ISLAMIC SCHOOL IN TURKEY
}

\author{
Raharjo \\ IAIN Walisongo Semarang \\ e-mail: joe.raharjo65@yahoo.co.id
}

\begin{abstract}
Selama berabad-abad Islam telah menjadi agama negara di Turki. Tetapi itu berubah saat Turki mendeklarasikan diri sebagai negara Republik pada tahun 1923. Turki menjadi negara sekuler dan membuat Islam tertekan. Namun saat sistem politik Pemerintah Turki mengadopsi multipartai dan partai itu kemudian didukung oleh masyarakat Muslim dan memimpin pemerintahan, perlahan keberadaan Islam kembali tampak. Kondisi ini memengaruhi keberadaan pendidikan dan sekolah-sekolah Islam, yang pada dua dekade terakhir jumlahnya meningkat tajam. Penelitian ini mengumpulkan data tentang kontrol kualitas pendidikan, bentuk-bentuk pendidikan Islam dan peran pemerintah terhadap pendidikan Islam. Melalui teknik dokumentasi, observasi dan interview, penelitian ini menunjukkan bahwa: 1) kontrol kualitas pendidikan di Turki dilakukan di bawah kementerian pendidikan nasional; 2) bentuk sekolah dibagi menjadi negeri dan swasta, dan 3) peran pemerintah terhadap sekolah-sekolah Islam tidak dilakukan secara langsung, namun melalui kebijakan Kementerian Pendidikan Nasional yang diberlakukan secara umum kepada sekolah negeri.
\end{abstract}

Islam had been the religion of the state in Turkey for many centuries, but it was disappeared when the type of the state was changed into republic in 1923. Turkey then has become a secular state and Islam has been depressed. However, when the political system in Turkey adopted multiparty and the party supported by Muslim community run the ruling government, Islam gradually has existed. This affected the Islamic education and schools, which have been sharply increased in number during the last 2 decades. This research was conducted to identify the quality control of education, the types of Islamic education and the role of government towards Islamic schools. By using techniques of documentation, observation and interview, this research indicated that: 1) the quality control of education in Turkey is done under ministry of national education; 2) the types of Islamic education are divided into public and private and 3) the role of government towards Islamic schools is not implemented straight forward, but through the policy in the Ministry of National Education addressed towards the public schools.

Keywords: quality control of education, Imam Hatip school, role of government 


\section{A. Preface}

Government has responsibility in educating its citizen. Process of educating people may be conducted through any types of education institutions. First, based on a basic belief, education institutions may be divided into religious and non religious education. Religious education itself may be differed from the teachings of Islam, Christian, Jew, etc. Second, based on an orientation, education may be oriented on academic and occupation. Academic orientation of schools prepares students to take further study (to university level), whereas those with occupation orientation provides students' ability and skills to work. īmām

Government as the national policy maker of education system has four main tasks, as follow: 1) Puts a quality standard of education institutions (schools); 2) Breakdowns the standard into several (more specific and operational) indicators, so that each school may easily pass the standard through fulfilling such indicators; 3) Supports the schools nationally at any aspects, including infrastructure (for example, buildings), teaching media and facilities, qualified teachers and education staffs, operational funds, and national regulations; and 4) Monitors and evaluates the progress of schools in a period of certain time. ${ }^{1}$

Those four points described above are one unified arrangement of responsibility of the government towards all education institution in order to reach the quality standard of education. Unfortunately, there are terms of state and private schools in many countries. State schools are schools established by government, and automatically managed and supported fully by the government, while private schools are schools established by a community either personally or collectively under a foundation. Consequently, the private schools are managed and supported by the non government organization. However, the government does not run away from its responsibility, as the availability of private schools really help the hard task of government in educating its citizen.

Turkey has a unique characteristic related to religion, which may include the system of its education. In Turkey, religious affairs are set out of state, whereas historically it had been an Islamic state, even become the center of Islamic civilization. But then, Turkey has been a secular state although most people who live there are Muslims. The national education system is also secular but there have always also been private organizations that run Islamic schools. Until last

1http://www.columbia.edu/ sss31/Turkiye/edu.html. Accessed on 8-10-2013. 
year however, it was harder to get into university from an Islamic school than from a general one. But now that new laws have leveled the playing field, Islamic schools have become more popular.

The number of religious schools in Turkey is increasing all the time, but some people are asking questions about the role of religion in education, and the goals of some of these religious schools. But whether Islamic schools are simply a way of preserving cultural traditions or whether they have another agenda remains a topic of debate. The role of government may strongly affect such a condition. This is an interesting point to be known through a research entitled 'the role of government in increasing quality of Islamic school in Turkey'.

The main problem of this research is "What is the role of government in maintaining and increasing the quality of Islamic school". Such a general problem is broken down into three specific ones, they are: 1) What is the quality control of education; 2) What are types of Islamic education; and 3) What is the role of government towards Islamic schools.

This research is a descriptive research. It is called so, as the data was collected to describe the reality of the topic that is the national policy of education system in Turkey. Subjects of this research are policy makers of education. They are people at any levels of policy, such as officers or staffs at educational ministry as well as schools' principals at operational level. Objects of this research are products of regulations on education at national level and their application at school level.

This research was conducted in Turkey for one month in October 2013. the centre of research was at Marmara University, Gostepe Campuss, Istanbul. However, the observation was done in an Imam-Hatip school, in Uskudar, Istanbul. This research combines library and field researches. The collected data will be in the type of sentences. It will be displayed in narrative description. So, the data will be analyzed in a quantitative manner.

\section{B. Review of the Literature}

\section{Education System}

Education in Turkey is governed by a national system which was established in accordance with the Ataturk Reforms after the Turkish War of Independence. It is a state supervised system designed to produce a skillful professional class for 
the social and economic institutes of the nations. ${ }^{2}$ Until 1977 children in Turkey obliged to take five years of education. The reforms 1997 introduced compulsory education for eight years. ${ }^{3}$ New legislation introduced in March 2012 prolonged compulsory education to 12 years. Primary and secondary education is financed by the state and free of charge in public schools, between the ages of 6 and 18, and by 2001 enrolment of children in this age range was nearly 100\%. Secondary or high school education is mandatory, but required in order to then progress to universities. ${ }^{4}$

\section{a. The Principles of the Turkish National Education}

According to the Constitution governing the Republic no one shall be deprived of the right of learning education. Further-more, primary education is compulsory and free in state schools. Except in specially licensed institutions Turkish must be taught as the mother tongue and religions instruction is a compulsory subject in the primary and secondary school curriculum. ${ }^{5}$

The following are the constitutional principles underlining the Turkish Educational system: ${ }^{6}$ (1) Universality and equality; (2) Fulfillment of individual and social needs; (3) Freedom of choice; (4) Right to education; (5) Quality of opportunity; (6) Education for all throughout life; (7) Adherence to Ataturk's reform principles including secularis; (8) Building of democracy; (9) Scientific approach; (10) Co-education; (11) School parent cooperation.

\section{b. The Goals of the Turkish National Education}

Goals of Turkish National Education: ${ }^{7}$ (1) To achieve 100 percent participation rate in elementary education ( $95 \%$ in 1986); (2) To raise the rate of literacy of the society which has already reached 85\%; (3) To emphasize technical and vocational education; (4) To extend comprehensive schools where multi-

\footnotetext{
${ }^{2}$ Ozelli, M. Tunc, "The Evolution of the Formal Education System and Its Relation to Economic Growth Plicies in the First Turkish Republic". International Journal of Middle East Studies, (London: Cambridge Universities Press), ISSN 0020-7438, Vol. 5 No. 1, January 1974, pp. 77-92.

3 Ilham Dulger. Turkey: Rapid Coverage for Compulsory Education - The 1997 Basic Education Program, May 2004. Accessed on 8June 2013.

42002 Report by Turkish Statistical Institute, Prime Minister of the Republic of Turkey.

${ }^{5}$ http://www.columbia.edu/ sss31/Turkiye/edu.html. Accessed on 8-10-2013.

${ }^{6} \mathrm{http}: / /$ www.columbia.edu/ sss31/Turkiye/edu.html. Accessed on 8-10-2013.

7http://www.columbia.edu/ sss31/Turkiye/edu.html. Accessed on 8-10-2013.
} 
purpose programs are to be offered to $60 \%$ of the children in secondary schools by the 1995-96 school year; (5) To take the necessary measures to raise the quality of national education; (6) To expand the provision of pre-school education so as to meet fully the demand for it.

\section{c. The Divisions of the Turkish National Education System}

The educational system in Turkey consists of two main divisions namely "formal" and "non-formal" education. Formal education covers the institutions of "pre-school education", "primary education", "secondary education", and "higher education". "Non-formal education" covers all other educational provision sponsored by the Ministry that occurs outside formal education.

\section{Schools in Turkey ${ }^{8}$}

\begin{tabular}{|l|l|}
\hline \multicolumn{1}{|c|}{ Formal Education } & \multicolumn{1}{|c|}{ Non-Formal Education } \\
\hline Pre-School (0-6) & Apprenticeship training centers \\
Kindergarten & Public training centers \\
\cline { 1 - 1 } Primary School (6-14) & Practical trade Schools \\
Public School & Adult Technical Training centers \\
Private Schools & \\
Regional boarding schools & \\
Special Education Schools & \\
\hline Middle Schools and Lycees (14-17) & \\
Middle Schools & \\
General Lycees & \\
Evening Middle Schools & \\
Science Lycees & \\
Anatolian High Schools & \\
\hline
\end{tabular}

Pre-primary education in Turkey is considered an adjunct to the public education system rather than an integral part of it. Most pre-primary schools are privately operated, though some attached to State primary schools. They are concentrated in the larger towns and cities, where they meet a need arising from the rapidly rising number of working mothers.

8http://www.columbia.edu/ sss31/Turkiye/edu.html. Accessed on 8-10-2013.

Walisongo, Volume 22, Nomor 1, Mei 2014 
The five year primary education is compulsory for every child as soon as they reach the age of six. Most elementary school students dress similarly in a type of uniform. Children who fail to reach the required standard at the end of any year may repeat it, and by this process it is possible for a child to remain in primary school until the age of 14 . Normally, however, the primary phase of basic education ends at age of 11 with award of a Primary School Certificate (Diploma).

The high school education is divided into two stages, each stage lasting three years, for a total of six years. The high school programs are not different than the programs in the United States. The main distinction in the classroom structure is that the teachers, instead of students, go from class to class.

Although general lycees remain the core of the secondary sector, there has recently been a growing emphasis on expanding the number and capacity of technical and vocational lycees. Furthermore, there are Technical Lycees, the specialized institutions and include the following specialized types: electricity, electronics, chemistry, machinery, motors, and building. Courses in technical lycees are designed to prepare students either for professional life or for further studying. Vocational Lycees (Secondary Schools) fall into 8 (eight) main types as follows: (1) Industrial Vocational Lycees; (2) Public Health Vocational Lycees; (3) Agricultural Vocational Lycees; (4) Animal Husbandry Vocational Lycees; (5) Girls' Vocational Lycees (home economics etc.); (6) Commercial Vocational Lycees; (7) Meteorology Vocational Lycees; (8) Land Registration and Cadastre Vocational Lycees.

Courses in these lycees are designed to prepare students for working life in their particular fields. Graduates can also apply for higher education.

\section{d. Educational Administration}

As with the overall administration of the country, educational administration is firmly centralized under the Ministry of Education. The Ministry is responsible for drawing up curricula, coordinating the work of official, private and voluntary organizations, designing and building schools, developing educational materials and so on. The Supreme Council of National Education discusses and decides on curricula, regulations etc. prepared by the Ministry. Educational affairs in the provinces are organized by the Directors of National Education appointed by the Minister. However, they work under the direction of the provincial governor. 


\section{e. Financing Education}

Public education at all levels receives major support from the central government, which is responsible for all educational expenses. Primary education is also supported locally, mainly for the construction and maintenance of schools. About $10 \%$ of the general budget is allocated for education. According to Mehmet Sağlam, (Deputy Speaker of Parliament) Turkey's education budget tripled between 2002 and 2011. ${ }^{9}$ The budget of the Ministry of Education increased from 7.5 billion lira in 2002 to 34 billion lira in 2011, making it the ministry with highest share of the national budget ${ }^{10}$ However, in 2002, the total expenditure on education in Turkey amounted to $\$ 13.4$ billion, including the state budget allocated through the National Ministry of Education and private and international funds. ${ }^{11}$

\section{Islamic Education}

Islamic Educations in Turkey are referred to three linked categories: religious movement, foundation and school. Most of them (private educations) run by community organizations ${ }^{12}$ and the others (public schools) organised and supported by the government.

\section{a. Religious Movements}

Economic and political liberalization during the administration of Turgut Ozal facilitated the development of a "religious market" in Turkey. Nakşibendi orders, the Fethullah Gulen movement, and the political National View movement of Necmettin Erbakan competed over the meaning and proper role of Islam in Turkish society. The Gulen movement has its roots in the Nurculuk movement of Said Nursi (1873-1960), who is best known as the author of the Risale-i Nur, the "Message of Light," a 6, 000-page commentary on the Quran.

${ }^{9} \mathrm{http}: / /$ www.todayszaman.com/news-264010-turkeys-education-budget-tripled-between-2002and-2011. html. Accessed on 8-10-2013

${ }^{10}$ Haberi Yazdir, "Bir numaralı bütçe Eğitim'e". Yeni Şafak (in Turkish) (sinop), 31 August 2008. Retrieved 9 June 2014.

11"Prime Ministry of the Republic of Turkey", 2002. Report by Turkish Statistical Institute.

12Rabasa, A. And Larrabee, F.S., The Rise of Political Islam in Turkey, (Santa Monica, CA: the RAND Corporation, 2008), pp. 15-17 
He argued that the time of the "jihad of the sword" was over, and that we are now in the era of the "jihad of the word, " meaning a reasoned attempt to reconcile science and rationalism with Islam. Nursi defended the rights of Armenians and Greeks in Turkey and reached out to Christian leaders. In 1950, he sent his collected works to Pope Pius XII and received in reply a personal letter of thanks. In the same way, in 1953, Nursi visited the Ecumenical Patriarch Athenagoras in Istanbul to seek cooperation between Muslims and Christians against atheism. ${ }^{13}$

Fethullah Gulen reinvented the Nur movement as "Turkish Islam." He departed from Nursi's emphasis on individual transformation and focused on the public sphere and on turning Islam into Islamic networks and social capital. The Gulen movement is active in promoting harmony among Islam, Christianity, and Judaism, and it sponsors a variety of fora for interfaith dialogue. ${ }^{14}$ A web of organizations propagates Gulen's vision of Islam. These include Fatih University in Istanbul and an extensive network of schools, hospitals, and charitable and media organizations, including the mass-circulation newspaper Zaman, television stations Samanyolu (Milky Way) and Mehtap (Full Moon), and the Englishlanguage Ebru satellite television station in the United States. The movement's holdings include a news agency (Cihan Haber Ajansı); the English-language daily Today's Zaman; a weekly newsmagazine, Aksiyon; an Islamic finance institution, Bank Asya (formerly known as Asya Finans); and an insurance company, Issık Sigorta. "Asya" is Turkish for Asia and resonates with the Gulen movement's extensive presence in Asian countries.

The Journalists and Writers Foundation (Gazeteciler ve Yazarlar Vakfi (GYV), associated with the Gulen movement, sponsors several dialogue platforms, including the Abant Platform (named after the location in western Turkey where the conferences take place), which brings together intellectuals and scholars to discuss national and international problems; the Eurasian Dialogue Platform, which includes representatives from Turkey and 12 countries in the former

${ }^{13}$ John L. Allen, Jr., "These two Islamic movements bear watching," All Things Catholic, National Catholic Reporter, June 22, 2007, at http://ncrcafe.org/node/1188 (as of March 21, 2008). See also Thomas Michel, S.J., "Muslim-Christian Dialogue and Cooperation in the Thought of Bediuzzaman Said Nursi," The Muslim World, Vol. 88, No. 3-4, July-October 1999, at http://www.blackwell-synergy.com/ doi/pdf/10.1111/j.1478-1913.1999.tb02751.x (as of March 21, 2008).

14The movement sponsored the performance of the traditional Mevlevi Sufi ritual by the Whirling Dervishes at the Washington Hebrew Congregation in June 2006, a remarkable presentation of an Islamic ritual in a Jewish religious setting. 
Soviet Union and Asia; and the Intercultural Dialogue Platform, which has organized Abrahamic meetings in Turkey, the Russian Federation, Georgia, Germany, and Sweden.15

The GYV also runs a large publishing enterprise that publishes books by Gulen and other Turkish authors on historical and sociological subjects, as well as a quarterly magazine. According to GYV officials, the movement's emphasis on Eurasia is explained by Turkey's historical and cultural links to Turkic-speaking peoples in the Russian Federation and the Central Asian republics, where the Gulen movement has also established a large number of schools. It also reflects the interests of businessmen associated with the movement. The Gulen movement has also developed a very effective international network beyond Eurasia, with many adherents in the United States (where the movement's founder lives). The Washington-based Rumi Forum organizes several intercultural trips to Turkey each year for U.S. residents to familiarize them with Turkish culture and the social work of the Gulen movement in Turkey. Secular Turks in mainstream Turkish-American organizations and in the Turkish Foreign Service often note that the secular Turkish diaspora is disorganized, fragmented, and inactive by comparison.

In addition to income from publishing, media, and financial enterprises associated with the Gulen movement, funding for the movement comes from donations by supporters, including wealthy Turkish businessmen. For example, one Gulen donor owns Ulker, Turkey's largest enterprise in many food sectors. The newspaper Zaman is owned by Ali Akbulut, a prominent textile manufacturer.

\section{b. Islamic Foundations}

Since Ottoman times, Turkey has had a tradition of Islamic foundations (vakiflar), and these remain a part of the Turkish scene in both urban and provincial settings. They have been important in a society where the social-welfare capacity of the state has been limited and often ineffective in bringing social services to new urban migrants. The Islamist political parties, from Refah to Saadet, and above all, the AKP, have been especially active in this area. In a very real sense, these

15The Abant Platform has held international conferences in Washington, D.C., in collaboration with The Johns Hopkins University School of Advanced International Studies (SAIS); in Brussels, with the Catholic University of Louvain; in Paris, with UNESCO and the Sorbonne; and in Cairo, with the al-Ahram Strategic Center. 
charitable and social-welfare activities have been the basis for the party's success at the municipal and national levels. As the AKP has become more entrenched in politics and society, it has also become more capable of raising charitable funds from like-minded (and some not so likeminded) contributors.

\section{c. Islamic Schools}

The proliferation of religious schools (Imam-Hatip) got under way in earnest during the Ozal period. The Imam-Hatip schools were established in the 1950s as vocational schools to produce qualified religious personnel. Their curriculum combines training in secular subjects with courses in religion. The schools generated a great deal of controversy, which appeared to be settled by the end of the Refah government and the introduction of regulations limiting their role. In fact, however, the issue of the Imam-Hatip schools remains highly controversial. The AKP government has been placing Imam-Hatip graduates in government departments and state-owned firms at all levels of responsibility.

This practice, along with the government's spring 2004 decision to introduce legislation aimed at giving the schools' graduates wider access to university and professional opportunities, spurred sharp opposition in secular circles. As Turks on both sides of the controversy are aware, the progressive introduction of AKP cadres, including Imam-Hatip graduates, into the state apparatus may be one of the leading vehicles for change in the secular-religious balance over time.

\section{Islamic School in Turkey}

The history of Islamic education in Turkey which has been going on several centuries ago, may be divided into three periods, according to Seyfi Kenan. They are clasic, modern and republic periods. The clasic period had been going on throughout the Ottoman Empire, in the 16th and 17th centuries, followed by the modern era in the 18th and 19th centuries. While the republic period began when Mustafa Kemal Attaturk took over the leadership of Turkey in 1923.

Islamic Schools in Modern Turkey begins with a thorough history of the Imam-Hatip Schools and their relationship to the Turkish state. According to Özgür:16

16İren Özgür Islamic Schools in Modern Turkey: Faith, Politics, and Education, (Cambridge: Cambridge University Press., 2012), pp. 26-27. 
The schools have experienced periods of prosperity and decline depending on how ruling governments have viewed them. Certain governments have considered (the) schools as threats to the secularist order and have taken measures to weaken them. Other governments have viewed (them) as tools for controlling religious discourse and have taken measures to develop them.

From the early days of the republic through to the contemporary era, the Turkish education system has mediated and underpinned the relationship between national belonging and the legitimacy of the state. In most public schools, the narrative of nationhood hinges on Atatürk's revolution itself while Islam plays a relatively smaller role, both inherent to Turks' collective past and awkwardly situated in relation to their ostensibly modernist, secularist present.

\section{The Quality Control of Education}

All education insitutions in Turkey are under control of the Ministry of National Education (MONE). According to the Unification of Education Law no 430 issued on 06-03-1924, the MONE is commissioned with the duty of reaching the goals set for Turkish National Education on behalf of the state. As stated in Law no 3797 issued on 30-04-1992 the duties of the MONE are: ${ }^{17}$

a. To plan, programme, implement, monitor and control education and training services targeted at teachers and students in the educational institutions at all levels affiliated to the Ministry with the objective of raising individuals who are committed to Atatürk's principles and reforms, and to the Atatürk's nationalism defined in the Constitution of the Republic of Turkey, who adopt, protect and develop the national, ethical, spiritual, historical and cultural values of the Turkish nation, who love and elevate their families, homeland and nation, who are aware of their duties and responsibilities to the Republic of Turkey - which is a democratic, secular and social state ruled by law based on human rights and the basic principles defined at the beginning of the Constitution - and who behave accordingly;

b. To open pre-primary, primary, secondary and all kinds of formal and nonformal education institutions, and to authorize educational institutions other than higher education institutions opened by other ministries, institutions and organisations;

\footnotetext{
${ }^{17}$ Republic of Turkey, Ministry of National Education, "Reviews of National Policies for Education: Basic Education in Turkey”, Background Report, June 2005, p. 10.
} 
c. To organize and implement education and training services abroad for Turkish citizens;

d. To define the degree of equivalency of diplomas and certificates of formal and non-formal education institutions except for higher education institutions opened by other ministries, institutions and organisations, and to prepare and approve their programmes and regulations in co-operation with the relevant institutions;

e. To establish co-operation in determining the curricula, regulations and degrees of educational equivalency of the secondary education institutions affiliated to the Turkish Armed Forces;

f. To fulfil the duties and responsibilities given to the Ministry by the Law on Higher Education to ensure that higher education is implemented within the framework of national education policy;

g. To provide physical education, sports and scouting training services in the schools;

h. To provide necessary accommodation, nutrition and financial support for the youth in higher education.

The aims and principles of Turkish National Education defined by the Basic Law of National Education numbered 1739 are as follows: ${ }^{18}$

a. To raise individuals who are committed to Atatürk's reforms and principles, his concept of nationalism as defined in the Constitution; who adopt, protect and improve the national, moral, human, spiritual and cultural values of the Turkish nation; who love and always elevate their families, homeland and nation; who are aware of their duties and responsibilities towards the Turkish Republic - which is a democratic, secular and social state ruled by law based on human rights and the basic principles defined in the beginning of the Constitution - and behave accordingly;

b. To bring up individuals who physically, mentally, morally, spiritually and emotionally have a moderate and healthy personality and mentality, independent and scientific thinking power, a wide world view; who respect human rights, appreciate enterprise and individuality; who feel responsibility towards the society; and who are constructive, creative and productive;

\footnotetext{
${ }^{18}$ Republic of Turkey, Ministry of National Education. "Reviews of National Policies for Education: Basic Education in Turkey”, Background Report, June 2005, pp. 16-17.
} 
c. To prepare individuals for life by ensuring that they have professions which will make them happy and contribute to the welfare of the society through equipping them with the necessary knowledge, skills, attitude and habit of working cooperatively in line with their own interests, talents and abilities.

Thus, the aim of Turkish National Education is to promote the welfare and happiness of the citizens and Turkish society, to support and accelerate economic, cultural and social development in national unity and cohesion, and finally to make the Turkish Nation a constructive, creative and distinguished partner of contemporary civilization.

\section{The Types of Islamic Education}

\section{a. Religious Education}

Historically, religious education in Turkey had a gloomy era, along with the unceasingly application of secular education system based upon Law Number 789 issued on 22 March $1926 .{ }^{19}$ In 1927, all courses concerning religion were excluded from the curriculum of primary, secondary, and high schools on the basis that non-Muslims also live in Turkey. The de-establishment happened in between the years 1927-1949, when religious instruction was not permitted in schools. In 1949, the Ministry of Education allowed a course on religion in $4^{\text {th }}$ and $5^{\text {th }}$ grades of primary school.

However, in 1956, as a result of multi-party democracy, a new government was established. Being more sympathetic towards the religious sentiments of society, this new government re-established religious education by introducing a religion course into secondary schools. This time, if the parents wanted to exempt their children from the course, they had to apply to the school with a written request. After nearly ten years, in 1967, the religion course was introduced to the 1st and 2nd grades of high school. Students, however, were enrolled for the course with the written request of their parents. In 1975, the course was extended to the third (last) grade of the high schools. And, finally, following the military coup in 1980, the religion course became schools was also constitutionally secured. The exact title of the course was, "The Culture of Religion and Knowledge of Ethics."

\footnotetext{
${ }^{19}$ Republic of Turkey, Ministry of National Education, "Reviews of National Policies for Education, Basic Education in Turkey”, Background Report, June 2005.
} 
Currently, religious education courses begin at the $4^{\text {th }}$ grade of primary school and continues throughout secondary and high schools ${ }^{20}$. From the $4^{\text {th }}$ to the $8^{\text {th }}$ grade, classes consist of two hours per week. At the high school level, there is one hour of class per week Thus, a student who has graduated from high school receives 8 continuous years of religion courses. There are no fixed books for the course. Rather, each school decides which book to follow — provided that the book for each level is approved by the Ministry of Education. Nearly half of the content of these courses concerns religion and Islam (whom majority are Muslims) with remaining topics ranging from secularism to humanism and from ethical values to etiquette. The major world religions such as Judaism, Christianity, Hinduism and Buddhism are included in the content of the course.

\section{b. Islamic Education Institutions}

In Turkey, Islamic Education Institutions are divided into three categories. They are informal, non formal and formal. Informal institution is a family, where children start to learn Islam from their parents, through the daily life activities. Other than learning at home, children the age of 5 also learn basic Islamic teachings, such as reading Quran, ablution, and prayers at mosques taught by ìmān of the mosque or at Islamic community centres. The Islamic community centres are used for gathering Muslim communities. The communities are divided into several groups, such as ladies group, children group, juvenile group and general group. Islamic teachings formally are then taught in 'Imam-Hatip schools'.

Imam-Hatip school (Turkish: Imam-Hatip Lisesi) is a secondary education institution. The terms 'Imam' and 'hatip' come from Arabic words. Imam means a leader of prayer; and 'hatib', means the one who delivers the "khuțba" or Friday sermon. As the name suggests, they were originally founded in lieu of a vocational school to train government employed imāms; after madrasas in Turkey were abolished by the Unification of Education Act (Turkish: Tevhid-i Tedrisat Kanunu) as a part of Atatürk's reforms21. The Imam-Hatip schools found a fortune of Turkey's Islamist movement, beginning with Necmettin Erbakan's National

\footnotetext{
20"Turkish government rules out demands of Islamic sect Alevis". Hurriyet. 2008-11-10. Accessed on 29-10-2013.

21Wikipedia, the free encyclopedia. http://en.wikipedia.org/wiki/\%C4\%B0mam_Hatip_school. Accessed on 27-10-2013
} 
Vision Movement (Milli Görüş Hareketi) in the 1970s, extending through the brief era of the Welfare Party (Refah Partisi) government in the 1990s and culminating in the ongoing heyday of the Justice and Development Party (Adalet ve Kalkınma Partisi, AKP). ${ }^{22}$

In 1913 the Medresetü-l Himmeti ve Hutaba (Schools for Education of Islamic Clerics) and Medresetü-I Vaizin (Schools for Preachers) were combined to form the tangible origins of today's Imam-Hatip high schools. In 1924 the TevhidTedrisat (Law of Unification of Educational Instruction) was passed, replacing existing pluralist modes of education with a secular, centralist and nationalist education system. The new law brought all educational institutions under the control of the Ministry of National Education. A Faculty of Theology at the Darülfünun (Istanbul University), special schools for training imāms and hatips (ministers and preachers) were opened by the new Ministry of National Education. However, in 1933 the Faculty of Theology was abolished and Imam-Hatip schools were discontinued due to a lack of student interest. ${ }^{23}$

In contrast to the strict secularist nature of the education policy of the Republican People's Party religious education was reinstated in 1948. This included the establishment of a Faculty of Theology at the University of Ankara in 1949. First steps for the establishment of Imam-Hatip schools began in 1951 under the Democrat Party government, which set up seven special secondary schools (Imam-Hatip Okullan). In addition, in 1959 Islamic Institutes were opened for graduates of Imam-Hatip schools. ${ }^{24}$

Since their creation in the 1950s, Imam-Hatips have been controversial in the debate about Turkey's secular state. Kenan Cayir, assistant professor of sociology at Istanbul's Bilgi University, says the schools can have a positive impact so that religion and modernity can be together. ${ }^{25}$ An objection to the free choice of ImamHatip graduates came from TÜSIAD (Turkish Industrialists' and Businessmen's

\footnotetext{
22İren Özgür Islamic Schools in Modern Turkey....

${ }^{23}$ The study of the Turkish Economic and Social Studies Foundation (tr: Türkiye Ekonomik ve Sosyal Etüdler Vakfi called Imam Hatip Liseleri: Efsaneler ve Gerçekler (Imam Hatip Schools: Legend and Reality) was published in October 2004. The 268-page document has an English summary (pages 3953) and can be downloaded as PDF-file. Accessed on 27-10-2013.

${ }^{24}$ The study of the Turkish Economic and Social Studies Foundation.

25Turkey, Religious Schools Gain a Foothold. An article in Voice of America of 25 September 2012. Accessed on 27-10-2013.
} 
Association. According to their research conducted in 1988, approximately $32 \%$ of graduates of Imam-Hatip schools picked faculties of law as their first choice in university entrance exams, proving more popular than religious based alternatives. The report concluded that, due to fundamental differences in their upbringing, Imam-Hatip graduates were rendered unsuitable for public office. Politicians tended not to agree with TÜSIAD's position. For example, the then Minister of National Education, Avni Akyol, criticised the report in terms of human rights, claiming such proposals undermined the principle of equal opportunity in education. ${ }^{26}$

Following the coup d'etat in 1960, Imam-Hatip schools encountered the threat of closure. Following the return to civilian politics and the introduction of the new constitution in 1961, graduates of Imam-Hatip schools could only enrol in university programmes if they had passed courses offered at secular schools. During the premiership of Süleyman Demirel however, graduates of Imam-Hatip schools were given access to university without any such stringent requirements. The 1971 Turkish coup d'état introduced two key reforms: firstly junior high Imam-Hatip schools were abolished, and in 1973 Imam-Hatip schools were renamed as Imam-Hatip high schools. Under the subsequent National Education Basic Law, Imam-Hatip schools were defined as vocational schools, where students were to be trained as preaches and ministers or prepared for higher education. ${ }^{27}$

Initially, Imam-Hatip schools grew slowly, but their numbers expanded rapidly to 334 during the 1970s. The coalition government of 1974, established by the CHP (Republican People's Party) and the MSP (National Salvation Party), committed to reopen junior high schools and giving the right of entry to university through examination. 230 new Imam-Hatip high schools were opened in a period of nearly four years. During the 1974-75 school year the number of students attending to the Imam-Hatip high schools grew to 48, 895. This number subsequently grew to 200,300 by $1980-81$. In addition, females gained the right of entry to Imam-Hatip high schools in 1976. The proliferation of Imam-Hatip high schools is often cited as the effect of the National Salvation Party's membership of a number of coalitions with Nationalist Front governments. ${ }^{28}$

\footnotetext{
26The study of the Turkish Economic and Social Studies Foundation.

27The study of the Turkish Economic and Social Studies Foundation.

${ }^{28}$ The study of the Turkish Economic and Social Studies Foundation.
} 
The coup d'etat of September 12,1980 is a critical turning point in the history of Turkey and also for the history of Imam-Hatip high schools. Under military governance, graduates of Imam-Hatip high schools gained the right of entry to all university departments. In 1985, two new Imam-Hatip high schools opened, one in Tunceli, despite of the so-called ethnic structure of the region, and the other in Beykoz as an Anatolian Imam-Hatip High School, with the aim of contributing to the education of children of families who work abroad. Although the number of Imam-Hatip high schools had not increased since, the number of students attending Imam-Hatip high schools has increased by $45 \%$. This is partly due to the improvement in the quality of Imam-Hatip high schools and the education offered at such schools..$^{29}$

Research indicates that between the years of 1993 and 2000, prospective students registered at Imam-Hatip high schools primarily to receive religious tutoring alongside a more general education ${ }^{30}$. In addition, research shows enrolment at Imam-Hatip high schools was based solely on the student's decision. The third proposed factor in the rise in popularity of Imam-Hatip schools is the admission of female students in 1976. By 1998, almost 100, 000 females attended Imam-Hatip high schools, making up almost half of all students. This statistic is particularly revealing because women are not eligible to become either priests or ministers. $^{31}$

However, the introduction of eight years of compulsory education in 1997 has seen a sudden decline in the popularity of Imam-Hatip schools. In 1999, the reclassification of Imam-Hatip schools as "vocational schools" meant that, although more options had been made available to graduates, attaining places at prestigious university courses became more difficult. By requiring that all eight compulsory years of schooling be spent under the same primary-school roof, middle schools were abolished. Children could not enter vocational schools (one of them the Imam-Hatip school) until the ninth grade (rather than the sixth, as before). ${ }^{32}$

\footnotetext{
${ }^{29}$ The study of the Turkish Economic and Social Studies Foundation.

30The TESEV reports cites studies of Suat Cebeci (1993), Türkmen (1998), Ünlü (1998)and Altunsaray (2000), on Wikipedia, the free encyclopedia. http://en.wikipedia.org/wiki/\%C4\% B0mam_Hatip_school. Accessedd on 27-10-2013.

${ }^{31}$ The study of the Turkish Economic and Social Studies Foundation.

${ }^{32}$ Andrew Finkel, "What's $4+4+4$ ?."An article by Andrew Finkel in the International Herald Tribune of 23 March 2012. Accessed on 27-10-2013.
} 
By the mid-1990s, Imam-Hatip schools were attracting some 11 percent of children in the relevant age group and developing into a parallel system of education. When the Justice and Development Party (AKP) came to power in 2002, only about 2 percent of eligible children attended clerical schools. The reform in education introduced in March 2012 extended mandatory schooling to 12 years and divided into four years of primary school, four years of middle school and four years of high school. . $^{33}$

Following the reforms of March 2012 that extended compulsory education to 12 years and allowed for Imam-Hatip schools to be opened and "middle school" level (second term of four years) experts warned that the possible increase in the number of Imam-Hatip schools was not in line with people's expectations and described it as a "top-down" process. Critics noted that the new education system seemed to be a revenge being taken for Imam-Hatip schools that were shut down after 1997. A survey conducted by the Turkey Imam-Hatip Alumni Foundation (TIMAV), revealed that the majority of Turks hold positive views about ImamHatip schools. The survey, titled "Perception of Imam-Hatip High Schools and Imam-Hatip Students in Turkey, " was conducted between April 24 and May 18, 2012 with 2, 689 people in 26 provinces. Most of the respondents were not Imam-Hatip graduates. ${ }^{34}$

The bill of March 2012 was written without public debate (or even discussion in the education ministry's own consultative body, the National Education Council) and it did not figure in the government's 2011 election manifesto. According to education specialists, the new measures would undermine educational standards and deepen social inequalities. The education faculties of most of Turkey's leading universities (including Sabanci University, Bosphorus University, Middle East Technical University and Koç University) all issued press statements describing the reforms of 2012 as hastily conceived, retrograde and out of step with current thinking. ${ }^{35}$

\footnotetext{
${ }^{33}$ Andrew Finkel, "What's $4+4+4$ ?"

${ }^{34}$ Turkey to launch new imam-hatip school for international students. An article in Today's Zaman of 2 September 2012. Accessed on 27-10-2013.

${ }^{35}$ Andrew Finkel, "What's $4+4+4$ ?"
} 


\section{c. The Role of Government towards Islamic Schools}

As a secular country, Turkey put religion out of goverment regulation. The religion affairs are including religious teaching and education. The secularism in Turkey is different from that in European Countries. Turkish government control religious development of the society, for example the imäms and hatips in all mosques in Turkey are the civil servants, and consequently are paid by government. The personnel of imāms and hatips are the graduates from faculty of Ilahiyat, who had perviousely passed Imam-Hatip school.

Based on government support, the quality of schools in Turkey is differentiated from their status of being public (state) school and private school. The public schools are state institution established by government, and thus supported financially by government, whereas the private schools are established by community and exclude from the government financial support.

Imam-Hatip school is one type of Islamic schools. It is established by the government, and there are still many Islamic schools that are not identified and concerned by the government. So, Imam-Hatip school is a public school, that supported by the government. The private Islamic teachings are conducted by Islamic family and community. They are conducted in the types of informal, non formal dan formal. Informal Islamic teachings are run by Muslim families and usulally held in houses and some mosques. These are especially addresses for pre-school children, to learn reading Quran and other basic Islamic teachings. Non formal Islamic teachings are conducted by Islamic communities and organizations, in the types of halaqah (informal meeting). The formal Islamic teachings, which are conducted in the types of schooling, are also established and organised by Islamic community and organisation. Hudayi is one of Islamic social organization in Uskudar, Istanbul, established and organised Islamic schools from primary to university levels. As the centre of 'tarikat naqsabandiyah' in Turkey. Hudayi also conduct routin and temporary Islamic informal meetings. Hudayi also provided scholarship for both domestic and overseas students. Those private schools are known but not supported formally by the government.

The concept of state school in Turkey is that the school is established by the Government. Government provides infrastructure (land, building and its facilities), teachers, curriculum and the regulations. The teachers are appointed and paid by the Government, and students have no pay the tuition. For example, 
at a high secondary school (LISE) of İmam-Hatip School in Oskudar İstanbul, ${ }^{36}$ each student is supported financially by the government as much as $3.000 \mathrm{TL}$ (Turkish Lira) equal to US\$1.500, - per year.

In state education institution, students are free of charge from primary level up to university (doctoral degree) level. If they pay, it is in small amount of money, as they are subsidised by the government. For example, Marmara University in Istambul Turkey serves lunch for students. Each student has to pay only $1 \mathrm{TL}$ (one Turkey Lira) for once lunch, whereas the lunch may be priced 12 to $15 \mathrm{LT}$ at out of campuss cafe ${ }^{37}$. All of facilities at public schools are funded by government. The size of classroom is $6 \times 5 \mathrm{M}^{2}$ (sequare metres) with 30 students in each classroom. This makes the classroom crowded, and consequently its teaching learning process is not quite effective. Therefore, many private schools that provide more conducive environment are also attended by many students.

New approaches and latest developments in education covered some aspects as follow. 38

1) Primary Education

In 1997 Law no. 4306 was put into implementation in line with the objective of $7^{\text {th }}$ Five-Year Development Plan (1996-2000), which envisages extending the duration of compulsory education from five to eight years until 2000 and in line with the recommendations of the Council of National Education that supported the objective. This Law states that the duration of compulsory primary education is eight years for all children between 6-14 ages. The Law also provided new resources as well as an increase in present resources. In order to support the extension of compulsory education to 12 years in 2012, some amendments have been made in the Law enabling secondary education institutions to make use of the income obtained within the scope of this Law.

\footnotetext{
${ }^{36}$ Observation on 25 October 2013, an intervier with Yusuf Ilyas Koq (a teacher).

37There are more than ten Indonesian students met at the university kitchen (10/10/2013). Some of them Azimah, 3rd semester undergraduate at faculty of ilahiyat (theology), from Magelang; Ahamad Nur Salim, 7th semester undegraduate at faculty of engineering from Sragen; Susilawati, 4th semester of doctoral degree at faculty of ilahiyat; Arif Darmawan, 3rd semester of master's degree at institute of social sciences, department of economic and economy growth, from Lampung; Muflihin, 3rd semester of master's degree at faculty of mathematic, from Bandung. Information was also collected from the director of International affairs at Marmara University, Dr. Mehmet Topak.

${ }^{38}$ Republic of Turkey, Ministry of National Education, Reviews of National Policies for Education: Basic Education in Turkey, Background Report, , June 200, pp. 48-49.
} 
2) Bussed Primary Education

Launched in the 1989/1990 academic year, Bussed Primary Education aims to provide education for the children of primary school age living in less populated and sparsely settled areas. It aims to reduce the number of schools with combined classes and offer more qualified education and training services. All transportation expenses are covered from the income of Law No. 4306. The Ministry of National Education (MONE) meets the needs of transported students such as transportation, lunch, books and stationery.

3) Free Textbooks

Free textbooks have been given to the primary education students who are children of lower income groups or rural families since the academic year of 1999/2000. A total of 12472292 primary education textbooks were printed by the Ministry and distributed all over the country during the academic year of 2002/2003. For the first time 81835281 primary education textbooks were distributed free to all primary education students in the 2003/2004 academic year. In the 2004/2005 academic year, 83749000 textbooks were distributed free to all primary students.

4) Regional Primary Boarding Schools (YIBO) and Boarding Primary Education Schools (PIO)

In order to provide primary education services to children of poor families and also to primary school age children living in villages and smaller settlement units that have no schools, Primary Boarding Schools (YIBO) and boarding primary education schools (PIO) were established. As of the 2004/2005 academic year 299 YIBOs and 280 PIOs serve also as the education-training and culture centres for their neighbourhoods. The Ministry gives a great deal of importance to provision of boarding opportunities at secondary education level to the graduates of YIBOs and PIOs, and to the uptake of students to the vacant quota boarding houses within the secondary education institutions.

In the last eight years, as a result of "Curriculum development" that has been carried out according to national needs and values and also taking contemporary scientific and technical data and also the differing interests, wishes and capabilities of the students into account, new curricula for schools of all kinds and levels have been developed and put into practice. The $5^{\text {th }}$ Government of Turkish Republic has developed and implemented an urgent action plan. The 
need to develop and change curricula according to the requirements of the present century and to the needs of the individual and society has been included in the Urgent Action Plan. Within this context, work to change and develop educational programmes was initiated within the "Project on Designing Educational Programmes at Primary and Secondary Education Level" and is being continued in a planned way.

Firstly, instead of teacher centred teaching model, a student centred teaching model was reflected in the new educational programmes. Secondly, a new school model was adopted. In this regard schools are intended as learning organisations by self-monitoring, self-developing and following new innovations. In this sense for realizing transformation, the curricula are regarded as guidelines.

Taking notice of the new information and experiences acquired through the recent developments in the world, the curricula are intended to develop in students: (1) intellectual learning skills such as reading, writing, speaking, listening, calculating, arithmetic, communication, observation, estimation and evaluation and using new information technologies; (2) capacity for thinking and reasoning through materials such as books, music, visual and performing art; and (3) psycho-motor capacity and perception capacity.

The curricula are based on the following: (1) take all the transformations and developments in the world as directive guidelines; (2) adopt EU standards and educational perspective of EU; and (3) consider the identification of the current educational problems of our country, the evaluation and the outcomes of the achievements and failures.

Basic approaches of the curricula are social, individual and economical. On the social approach, the curriculum aims at: (1) bringing up students as a member of a knowledge society in parallel with the changes and development in the world; (2) raising students who are conscious of their duties and responsibilities, and in harmony with their community; (3) bringing up individuals who are sensitive to the issues of importance for society; (4) bringing up individuals who are sensitive to the problems of handicapped and gifted students; (5) raising individuals who are aware of the fact that democracy entails a sense of mutual duty and responsibility among individuals, that individuals in a democracy have not only rights but also duties; and (6) raising consciousness of basic human rights.

On the individual approach, the curriculum aims at: (1) accepting the fact that every student is a separate individual; (2) aiming at achieving personal happiness 
and pleasure of success in students; (3) providing guidelines for the future life of the student; (4) aiming to develop competencies in individuals which are necessary for our age; (5) giving priority to raise students as healthy individuals in terms of physical and psychological health; (6) giving priority to learning to learn; (7) ensuring that all students receive the message that they are reliable individuals and transfer this message in to a life principle.

On the economical approach, the curriculum aims at: (1) accepting the idea of achieving sustainable economical development; (2) taking into account regional economic differences; (3) taking necessary measures in order to meet professional manpower demands required by the economy.

Curriculum development studies continue, in co-operation with the universities, on Turkish, Maths, Knowledge of Life, Social and Science for primary schools, and Turkish Language and Literature, Maths, Physics, Chemistry, Biology, History and Geography for secondary schools. The curricula are being revised taking into account innovations in technology, the subject field, educational sciences and European Union standards. Specialized commissions were established, and needs analysis was conducted for the subjects in line with the opinions obtained in a democratic way from non-governmental organisations, universities, inspectors, administrators and teachers.

Within the context of "National Education Development Project" studies, reports measuring educational activities and exams, reports of TIMSS-R Test and Questionnaire and PIRLS Project Test and Questionnaire results were also used. The commission has been working on basic competencies that every student should have in the subject field, forming 12-year curriculum patterns (for primary and secondary education) conducting of skill analysis for each course, and forming concept maps and relation analysis between courses. Materials suitable for education and training programmes and information technologies and guidebooks for teachers are prepared in line with the curriculum development studies.

\section{Discussion}

Islam in Turkey has a unique groove, going up and down, marked by political revolution and evolution. During Ottoman Empire, Islam had been the religion of the country. For four centuries, the government had been ruled based on Islam. 
As an Islamic country, all patterns of daily life activities applied Islamic teachings. So education in all types also had a spirit of Islamic teaching, as the aim of national education at the time was to attain the true Muslim.

Between $15^{\text {th }}$ and $19^{\text {th }}$ centuries, the global Islamic civilization had been slightly decreasing. It might also happen in Turkey, when some states under Turkish regime, in the last century of Ottoman Empire, had separated and been independent countries. However, the policy of national education had been modernised, and many students were sent overseas to study the modern sciences and technologies. Most of students studied in European countries, whose the ideology was secular. By end of $19^{\text {th }}$ to early $20^{\text {th }}$ century, the global Islamic civilization had risen up, indicated by modern Islamic movement inspired by prominent figures such as Rasyid Ridlo, Jamaluddin Al Afghani and Muhammad Abduh. But, eventhough the national education had progressed better in the early $20^{\text {th }}$ century, Islam in Turkey began to enter the gloomy era, revolution happenned, when Mustafa Kemal Ataturk took over the regime and changed totally the foundation of the country from Islam to secular. The power of Ataturk was unsurpassed, so that he succeded to do whataver he wanted inculding to ebolish any Islamic simbols of people in daily life activities (e.g. lady wearing head scarf) and pull out Islamic teachings from the national curriculum of schools. The Islamic schools that had existed during the Ottoman Empire (madrasas) and lasted in the early Republic of Turkey (Imam-Hatip schools) were closed totally in 1927.

The ban of Islamic teaching from the curriculum as well as the existence of Islamic schools in Turkey had been going on for more than 3 decades, until 1950s when the multi party was applied there. Since then, Imam-Hatip schools have ben reopenned and lasted to the recent time. The national policy toward the ImamHatip school as one of public vocational schools had also been changeable. In the beginning time, it was very restricted that the aim of establishmnet of Imam-Hatip school was only to produce professions of imäms and hatips in mosques. The graduates of Imam-Hatip schools were not allowed to continue their study in other disciplin other than faculty of illahiyat at a university level. Consequently, students of Imam-Hatip school were very limited as there were so many elective professions could be taken through the other types of schools. Moreover, there was no girl became student of Imam-Hatip school, as in Islam there is no woman allowed to be an imām in mosques or a hatip at Jumah prayer. 
In the following time, the regulation applied on the Imam-Hatip school had been gradually loosed. The application of national policy toward Imam-Hatip school has been going in evolution, step by step, took more than 3 decades from 1950s to 1970s. The main progress happenned in the policies on Imam-Hatip school were that: (1) the curriculum did not only contain Islamic teachings but also general knowledge; and (2) the graduates were allowed to take further study at any disciplin of knowledge an at any university. This policy was welcome by most Muslim community in Turkey and made Imam-Hatip school developed very rapidly. Not only boys but also girls enrolled in that school. In 10 years, until late 1980s, there had been more than 300 Imam-Hatip schools established in Turkey, and up to 2014 it was planned to have more than one thousand Imam-Hatip schools.

The rapid growth of Imam-Hatip schools nowadays does not happen accidentally. It has been planned and struggled through many ways. There were many underground movements, such as a faith movement that has played a vital role in the revival of Islam in Turkey inspired by Bediüzzaman Said Nursî (1878March 23, 1960) ${ }^{39}$ and social Islamic movement led by Muhammed Fethullah Gülen (born 27 April 1941) ${ }^{40}$. When every movement to support the existence of Islamic teaching came up into surface, there would be resistance from the ruling regim.

When Necmettin Erbakan was appointed to be The Prime Minister in 1996, his National Vision Movement was based on Islamic movement. This was the beginning of Imam-Hatip schools finding the fortune. Unfortunately, the movement got a resistance from the opponent parties, which then mobilized the military power to step down Erbakan from a prime minister through a cold coup de'etat in 199741. However, since then, the growth of Imam-Hatip schools went on unobstructively, extending through the brief era of the Welfare Party (Refah Partisi) government in the 1990s and culminating in the ongoing heyday of the Justice and Development Party (Adalet ve Kalkinma Partisi, AKP). ${ }^{42}$

So far, Turkey is still a secular country. It may be the way to maintain Ataturk Reforms or to have similarities among countries in the European Union, but

\footnotetext{
${ }^{39} \mathrm{http}: / /$ en.wikipedia.org/wiki/Said_Nurs\%C3\%AE, accessed on 10-11-2013.

${ }^{40} \mathrm{http}$ ///en.wikipedia.org/wiki/Fethullah_G\%C3\%BClen, accessed on 10-11-2013.

${ }^{41} \mathrm{http}: / /$ en.wikipedia.org/wiki/Necmettin_Erbakan, accessed on 10-11-2013.

${ }^{42}$ İren Özgür, Islamic Schools in Modern Turkey....
} 
Islamic movements find a conducive position. The model of secularism in Turkey is different from that in Europe. Turkey recently led by Recep Tayyip Erdoğan (the third term as the Prime Minister since 200343) gives attention to Islam. Erdogan was a graduate of Imam-Hatip school, he is a Muslim and religious person. Therefore, he has a mission to support Islamic movements through many ways including policy of National Education System, especially related to Islamic schools. However, he is still careful to implement such a policy in order to run smoothly. He performs an integrated ideology of secular and Islam.

The attention of the government to Islamic schools in Turkey, is not straightforward. Education institutions in Turkey is differed according to a status of being public and private. Public schools are established by the government, and so the organisastion and financial support are also come from the government. Imam-Hatip school is one of the public schools. Toward the public schools, the government provides the land, builds the buildings, selects and pays the teachers, and supports the fund. The schools are free of charge for students. The students are not only free from paying tuition, but they are also subsidised in their food for luch (prepared by the schools), provided boarding houses, school buses, and textbooks.

\section{E. Conclusion}

The quality control of education in Turkey is done under ministry of national education. All school institutions established by social organization or ministry other than national education must have a permission from the ministry of national education. The government provide infrastructures, learning facilities, teaching staffs and financial support to public schools. But the government does monitoring and evaluation towards both public and private schools.

Types of Islamic education in Turkey are vary. Based on the status, the schools are divided into public and private. The public schools are established by government, while the private schools are established by community organizations. The public schools whose curriculum contains Islamic teachings are called Imam-Hatip school. This is the only Islamic school that teaches Islam, which at the beginning was aimed only to produce imām and hatip profesions in $11-2013$

${ }^{43}$ http://www.britannica.com/EBchecked/topic/913988/Recep-Tayyip-Erdogan, accessed on 10- 
mosques. In the continuing era, the Imam-Hatip school also teaches other discipline of knowledge, so that the graduates may continue their study to learn broader knowledge in any university. The private schools are various, as there are various community organizations. Private Islamic education is conducted initially at the family as an informal education. The second centre of private Islamic education is mosques that is taught by the imām. The Islamic education is also held formally in schools as well as nonformally in community centres.

The role of government in maintaining and increasing the quality of Islamic school is not implemented straight forward. The goverment support Imam-Hatip school as part of public schools through the policy of ministry of national education. The government ebolish some bans of existence of Islamic symbols in public through the national policy of the government. the government ignores (does not disturb) the development of Islamic sosial and spiritual movement conducted by Muslim community. And the government organises and controls activities of religious affairs under the Presidency of Religious Affairs.[w] 


\section{BIBLIOGRAPHY}

Alasania, G. and Gelovani, N., "Islam and Religious Education in Turkey", Journal on International Black Sea University, Vol. 5, No. 2, 2011, pp. 35-50.

Amiruddin, M.H., "The Development of Islamic Education In Turkey", The $4^{\text {th }}$ International Conference on Aceh and Indian Ocean Studies (ICAIOS) 2013.

Haberi Yazdir, "Bir numaralı bütçe Eğitim'e". Yeni Şafak (in Turkish), Sinop, 31 August 2008. Retrieved 9 June 2014.

İren Özgür, Islamic Schools in Modern Turkey: Faith, Politics, and Education. Cambridge: Cambridge University Press, 2012.

Mehmet Toprak, "Religious Groups in Turkey", Paper presented in a seminar at Faculty of Ilahiyat, University of Marmara, Istanbul, October 2013.

Ozelli, M. Tunc "The Evolution of the Formal Education System and Its Relation to Economic Growth Plicies in the First Turkish Republic". International Journal of Middle East Studies, London: Cambridge Universities Press, Vol. 5, No. 1, January 1974, ISSN 0020-7438, pp. 77-92.

Prime Ministry of the Republic of Turkey. 2002 Report by Turkish Statistical Institute.

Rabasa, A. and Larrabee, F.S., The Rise of political Islam in Turkey, Santa Monica, CA: the RAND Corporation, 2008.

Republic of Turkey, Ministry of National Education. Reviews of National Policies for Education: Basic Education in Turkey, Background Report, June 2005, p. 10.

Zubaida, S., Turkish Islam and National Identity, MER 1999.

\section{Internet:}

Andrew Finkel, "What's $4+4+4$ ?" The International Herald Tribune. 23 March 2012. Accessed on 27-10-2013.

http://en.wikipedia.org/wiki/Fethullah_G\%C3\%BClen, accessed on 10-11-2013

http://en.wikipedia.org/wiki/Necmettin_Erbakan, accessed on 10-11-2013.

http://en.wikipedia.org/wiki/Said_Nurs\%C3\%AE, accessed on 10-11-2013. 
http://www.britannica.com/EBchecked/topic/913988/Recep-Tayyip-Erdogan, accessed on 10-11-2013.

http://www.columbia.edu/ sss31/Turkiye/edu.html. Accessed on 8-10-2013.

http://www.mymerhaba.com/Islam-in-Turkey-118.html. Accessed on 10-102013.

http://www.todayszaman.com/news-264010-turkeys-education-budgettripled-between-2002-and-2011. html. Accessed on 8-10-2013.

http://www.wikipedia.org/wiki/Education_in_Turkey\#Pre-Primary-Education. Accessed on 8 June 2013.

Ilham Dulger "Turkey: Rapid Coverage for Compulsory Education - The 1997", Basic Education Program, May 2004. Accessed on 8 June 2013

John L. Allen, Jr., "These two Islamic movements bear watching, " All Things Catholic, National Catholic Reporter, June 22, 2007, at http://ncrcafe.org/ node/1188 (as of March 21,2008).

The Study of the Turkish Economic and Social Studies Foundation (tr: Türkiye Ekonomik ve Sosyal Etüdler Vakfi called Imam-Hatip Liseleri: Efsaneler ve Gerçekler (İmam-Hatip Schools: Legend and Reality) was published in October 2004. Accessed on 27-10-2013.

The TESEV reports cites studies of Suat Cebeci (1993), Türkmen (1998), Ünlü (1998) and Altunsaray (2000), on Wikipedia, the free encyclopedia. http://en.wikipedia. org/wiki/\%C4\%_Imam_Hatip_school. Accessedd on 27-10-2013.

Thomas Michel, S.J., "Muslim-Christian Dialogue and Cooperation in the Thought of Bediuzzaman Said Nursi, " The Muslim World, Vol. 88, No. 3-4, JulyOctober 1999, at http://www.blackwell-synergy.com/doi/pdf/10.1111/ j.1478-1913.1999.tb02751x (as of March 21, 2008).

Turkey to launch new imam-hatip school for international students. Today's Zaman. 2 September 2012. Accessed on 27-10-2013.

Turkey, Religious Schools Gain a Foothold. Voice of America. 25 September 2012. Accessed on 27-10-2013.

Wikipedia, the free encyclopedia. http://en.wikipedia.org/wiki/\%C4\%B0mam_ Hatip_school. Accessed on 27-10-2013. 
